\title{
Abstracts of Organized Symposia
}

\section{A Content Analysis of the Northeastern Journal of Agricultural and Resource Economics (NJARE): 1978-87.}

\author{
Organizer and Moderator: C. M. Gempesaw II (University of Delaware) \\ Speakers: Catherine Halbrendt (University of Delaware), C. M. Gempesaw II (University of Delaware), \\ James W. Dunn (Penn State University), and Cleve Willis (University of Massachusetts)
}

In the last ten years, the NJARE has undergone several important changes. Since 1978, the Journal has had four different editors. In 1983, the membership voted to discontinue the practice of publishing selected papers presented at the Northeast Agricultural and Resource Economics Association (NAREA) annual meetings. In 1984, the Journal's name was changed from Journal of the Northeastern Agricultural Economics Council to the present NJARE and the size and typeset were improved. During the 1983 annual business meeting, it was noted that a possible impact of not publishing selected papers is that the Journal editor would have control over the contents of both issues of the Journal. It was also argued that the Journal might become an irrelevant outlet for publication by the NAREA members if the editor has a narrow view in terms of subject matter and methodology.

Catherine Halbrendt provided an overview of the focus and trends of the American Joumal of Agricultural Economics for the last 25 years. C. M. Gempesaw II discussed the content analysis of the NJARE covering the 1977-87 period. James Dunn provided his own observations on the content analysis results and discussed the characteristics of both accepted and rejected papers submitted since 1987. Cleve Willis also offered his own perspective on the content analysis results. In addition, he also addressed the various issues cited above by providing data on the characteristics of all papers submitted during his editorial term. 


\section{Undergraduate Teaching in the Northeast: Alive?, Well?}

Organizers: Steven E. Hastings (University of Delaware, Chairman), Johannes Delphendahl (University of Maine), and Dennis K. Smith (West Virginia State University).

Moderator and Presenters: Steven E. Hastings (University of Delaware, Moderator), Johannes Delphendahl (University of Maine), Thomas Brewer (The Pennsylvania State University), John E. A. MacKenzie (University of Delaware), and Kenneth McIntosh (West Virginia University)

Many undergraduate agricultural economics teaching programs in the Northeast are under going drastic changes in response to a variety of new demands by students, faculty and administrators. Some are experiences expanding enrollment; others are facing decline. Some face resource constraints. This symposium allowed five faculty/administrators who either are or have been involved in undergraduate teaching to share their views on critical issues in this area.

Dr. McIntosh described the trends in undergraduate enrollment and teaching resources at West Virginia University. He postulated a "stickyness" in the allocation of resources in response to changing enrollment. Dr.
Delphendahl described important characteristics of agricultural economics programs in the New England universities. Significant variety exists. Dr. Kezis presented a summary of University of Maine's program, highlighting strengths and weaknesses, teaching innovations and recruitment activities. Dr. Brewer highlighted the program at Pennsylvania State University. He commented on student strengths and weaknesses and the treatment of teaching in the promotion and tenure process. Dr. Mackenzie offered some philosophical thoughts on the justification and purpose of an undergraduate program in agricultural economics. He also described the recent renovation of the program at the University of Delaware. 


\title{
Agricultural Economics Research in the Northeast: Programs and Implications for the Future
}

\author{
Organizer: Clark Burbee (USDA-CSRS) \\ Moderator: Julie A. Caswell (University of Massachusetts) \\ Speakers: Clarence Davan (Davan Consulting International, Inc.), Roland Robinson (USDA-CSRS), \\ and Paul Farris (Purdue University)
}

Several reports appearing in recent years have called for a reexamination of the research priorities of agricultural economists. To further this reexamination, the Cooperative State Research Service (CSRS) of USDA has undertaken studies of past and current state research programs and priority topics for the future. The results of three such studies were presented and discussed in this symposium. Clarence Davan reported on the results of interviews conducted on behalf of CSRS with a variety of agribusiness interests, elected officials, and consumer groups to identify and give priorities to researchable questions in agricultural economics. Roland Robinson discussed a new data base developed by CSRS to clas- sify, by topic area, research being done at state agricultural experiment stations. These data show a great deal of variance between states in sources and uses of research funds for agricultural economics research. Paul Farris reported on changes in total, federal, and nonfederal funding of economics and marketing research through state agricultural experiment stations between 1970 and 1985. Over this time period, federal funding of agricultural marketing economics research decreased substantially but increases in nonfederal funding, primarily state appropriations, offset much of the relative reduction in federal support. 